\title{
Effects of shoreline erosion on salt-marsh floral zonation
}

\author{
Ryan M. Moody ${ }^{1, *}$, Just Cebrian ${ }^{1,3}$, Sara M. Kerner ${ }^{2}$, Kenneth L. Heck, Jr. $^{1,3}$, \\ Sean P. Powers ${ }^{1,3}$, Carl Ferraro ${ }^{4}$ \\ ${ }^{1}$ Dauphin Island Sea Lab, 101 Bienville Blvd., Dauphin Island, Alabama 36528, USA \\ ${ }^{2}$ Department of Biological Sciences, Florida Institute of Technology, 150 West University Blvd., Melbourne, \\ Florida 32901, USA \\ ${ }^{3}$ Department of Marine Sciences, University of South Alabama, LSCB 25, Mobile, Alabama 36688, USA \\ ${ }^{4}$ State Lands Division Coastal Section, Alabama Department of Conservation and Natural Resources, \\ 31115 Rivers Blvd, Spanish Fort, Alabama 36527, USA
}

\begin{abstract}
The loss of salt-marsh habitat is proceeding at an alarming rate worldwide, resulting in the loss of ecosystem function and reduced exchange with adjacent habitats. The immediate result of shoreline erosion is the loss of fringing vegetation, but it is unclear how, and at what temporal scale, intertidal floral zones respond to shoreline loss. Using a transect-based approach over a 3 yr period, we compared community composition among 3 intertidal salt marshes in coastal Alabama that differ in the intensity of wave-generated disturbance. Each study marsh exhibited net annual rates of shoreline retreat, but differed in its exposure to wave-induced disturbance and erosional state. We also examined whether wave attenuation by oyster breakwaters reduced annual rates of shoreline erosion, providing a means to test whether the intensity of shoreline erosion affects inter-annual patterns of marsh zonation. Community composition differed across sites, but not between breakwater treatments and site-specific rates of shoreline loss, suggesting that differences in community composition are not due to differences in erosion intensity, but to other contrasts across sites. The cohesive nature of the floral communities at each site suggests that marshes maintain their zonation structure by migrating inland as the shoreline recedes. The inland migration of marsh zones will, however, ultimately be limited by the lack of area available for marsh colonization. The preservation of coastal salt marshes is, therefore, vitally contingent on effective shoreline management strategies.
\end{abstract}

KEY WORDS: Community $\cdot$ Erosion $\cdot$ Flora $\cdot$ Gulf of Mexico $\cdot$ Living shorelines $\cdot$ Salt marsh

\section{INTRODUCTION}

Disturbance is a fundamental force that acts on every level of community organization over a variety of spatial and temporal scales (Pickett \& White 1985, White \& Jentsch 2001). The frequency, intensity, and duration of disturbance influences community structure through its effects on biotic interactions, including predation, competition, and facilitation (Paine 1974, Bruno et al. 2003). By opening substrate for colonization and limiting competitive exclusion, dis- turbance often sets the stage for successional processes and, as a result, plays a key role in generating diversity in marine ecosystems (Connell 1978, Petraitis et al. 1989, Paine et al. 1998, Sousa 2001, Fraterrigo \& Rusak 2008).

Salt-marsh floral communities are organized into distinct zones along landward-to-seaward gradients (Pomeroy \& Wiegert 1981, Bertness \& Ellison 1987, Levine et al. 1998, Emery et al. 2001). Species inhabiting the stressful, low intertidal zone are typically able to withstand long periods of inundation, anoxic 
sediments, and considerable daily fluctuations in temperature and salinity (Niering \& Warren 1980, Mendelssohn et al. 1981, Pomeroy \& Wiegert 1981). Disturbances such as ice-scouring, wave-induced erosion, catastrophic storm events, wrack deposition, and persistent drought conditions also influence the structure of marsh communities by generating heterogeneous patchworks of successional change (Bertness \& Ellison 1987, Levine et al. 1998, Bruno \& Kennedy 2000, Silliman et al. 2005).

In the western Atlantic, a large tidal range supports expansive meadows of smooth cordgrass, Spartina alterniflora. In contrast, tidal ranges in the northern Gulf of Mexico (GOM) are narrow (typically 0.4 to $0.6 \mathrm{~m})$, permitting the black needlerush Juncus roemerianus to dominate the mid and high intertidal zones. Consequently, $S$. alterniflora is often relegated to fringing bands and isolated patches at the seaward edge (Stout 1984, Levine et al. 1998). S. alterniflora and $J$. roemarianus are the typical dominant floral species in Gulf marshes, and their zonation patterns are driven by the inability of $J$. roemerianus to thrive in the stressful conditions of the low intertidal. Fringing marshes exposed to moderate- and highenergy wave conditions in the GOM are often characterized by steeper shoreline slopes. This, in combination with the narrow tidal range in the region, often leads to compressed patterns of floral zonation within narrow vegetation bands.

Due to their location at the land-sea interface, salt marshes mitigate coastal erosion and buffer adjacent uplands from storm events, filter land-derived nutrient pollution before it enters coastal waters, and provide habitat for many ecologically and economically important finfish and shellfish species (Kneib \& Wagner 1994, Peterson \& Turner 1994, Minello et al. 2003). Marshes trap and bind sediments, which allows for the accumulation of below-ground biomass and marsh maintenance (Morgan et al. 2009). The accretion of sediment ultimately facilitates a rise in the elevation of the marsh surface, and a gradual seaward progression of the marsh edge (Gleason et al. 1979, Pomeroy \& Wiegert 1981). These processes have been slowed, and in many cases reversed, as a result of anthropogenic coastal hydrological modifications, coastal subsidence and uplift, natural shifts in wind and current regimes, and accelerated sealevel rise (reviewed by Kennish 2001, Gedan et al. 2009, Prahalad et al. 2011). Indeed, loss of fine sediments and subsequent shoreline erosion is one of the most serious problems that marshes face in many areas of the world (Syvitski et al. 2005). For instance, rates of shoreline loss exceeding $0.3 \mathrm{~m} \mathrm{yr}^{-1}$ result in a net loss of fringing salt marshes, and annual rates of shoreline loss in excess of 2 to $3 \mathrm{~m} \mathrm{yr}^{-1}$ have been documented for decades along the Atlantic and northern GOM (Phillips 1986, Smith 1990). European marshes have also experienced increased rates of shoreline erosion in recent decades as a result of increased wave height, tidal fluctuations, and sediment loss due to bioturbation (Wolters et al. 2005, Möller 2006).

Living shoreline initiatives have been proposed as effective and environmentally friendly alternatives to bulkheads and seawalls for protecting shorelines and curbing the erosion trends observed world-wide (NRC 2007). Living shorelines are structures composed of biogenic materials, such as oyster clutch, that are deployed seaward of eroding shorelines in an effort to revert that trend, stabilize the shoreline, and create healthy coastal habitat. In the northern GOM, restored oyster reefs are a favored model for living shoreline approaches (Meyer \& Townsend 2000, Peterson et al. 2003, Coen et al. 2007, Scyphers et al. 2011). Indeed, subtidal oyster reefs naturally occur adjacent to U.S. intertidal marshes and, in addition to their role as biogenic habitat for finfish and shellfish communities, they further serve to attenuate erosive wave action, stabilize sediments, and reduce marsh retreat (Dame \& Patten 1981, Meyer et al. 1997).

Little is known about how shoreline erosion and retreat affects the distribution and zonation of marsh communities in marshes of the west Atlantic and northern GOM. Addressing this gap is important to our understanding of the resilience of salt-marsh habitats in the face of both acute and chronic stressors. Specifically, it will provide insight into the maintenance of floral diversity, effects on primary production and the accumulation of organic material, the capacity for sediment filtration and trapping, and shoreline protection (Morgan et al. 2009).

In this paper, we examine patterns of marsh zonation across a range of shoreline erosion intensity. Three sites with net annual rates of shoreline retreat, but differing in their erosional state and exposure to wave-induced disturbance, were studied. We also examined whether the deployment of oyster reefs across the degrading shorelines reduced annual rates of shoreline erosion, thereby permitting us to experimentally test whether the intensity of shoreline erosion affects patterns of marsh distribution and zonation from year to year. In particular, our study was designed to identify key changes in floral zonation in response to wave-induced shoreline erosion and the potential for floral zones to remain intact 
through upland migration along the intertidal gradient. We hypothesized that shorelines with low rates of shoreline loss would retain their natural zonation pattern through time as the entire assemblage migrated landward, despite losses of areal coverage. In contrast, we did not expect marshes with shorelines subject to intense erosion to respond rapidly enough, resulting in a loss of entire floral zones at the marsh fringe. Finally, we predicted that experimental plots with oyster breakwaters would exhibit lowered rates of shoreline loss and a greater retention of floral zonation structure, relative to unprotected controls.

\section{MATERIALS AND METHODS}

\section{Study sites}

Rates of shoreline loss and floral zonation were assessed at 3 eroding locations in coastal Alabama: South Point-aux-Pins (SPaP); Northeast Point-auxPins (NEPaP); and Alabama Port (AP; Fig. 1). The dominant wind direction in the study area is from the south/southeast during summer and spring, and from the north during winter (Schroeder \& Wiseman 1985,

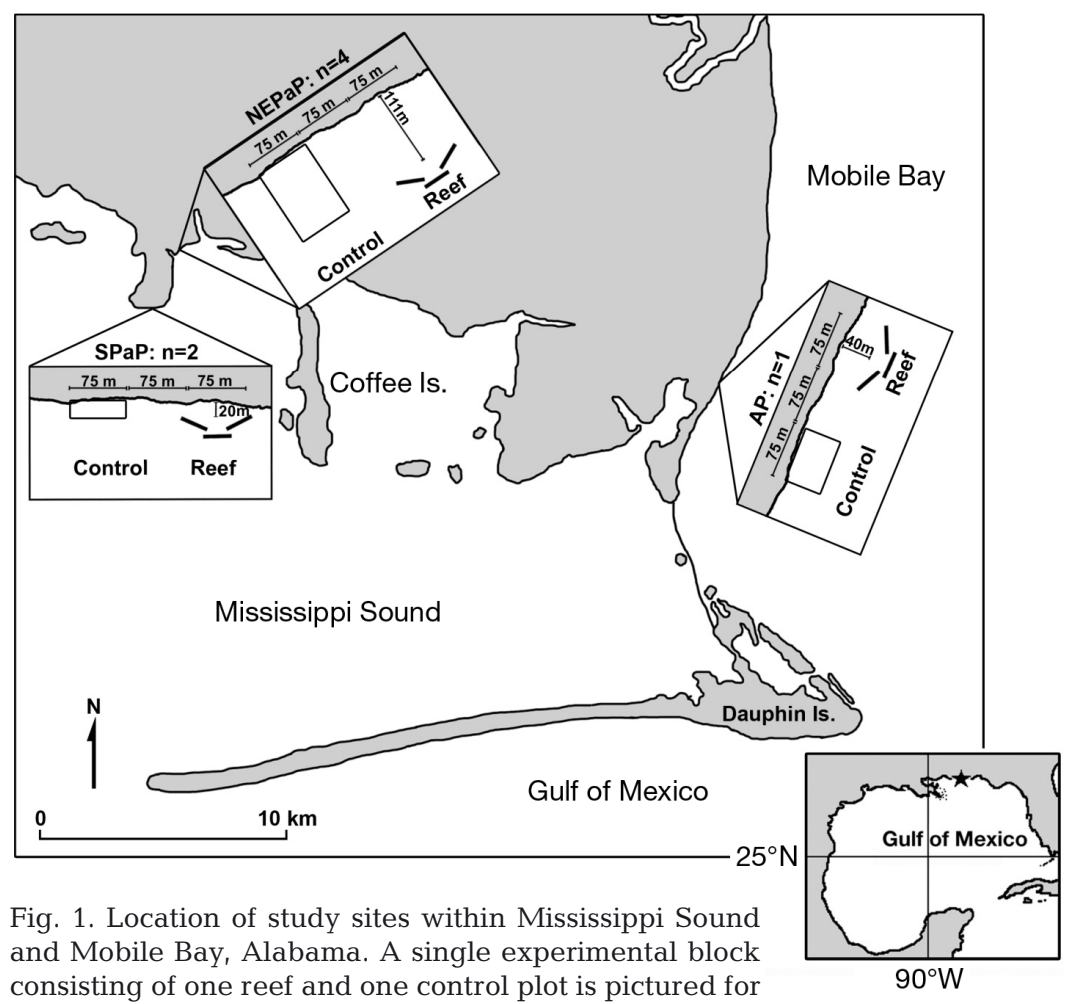

consisting of one reef and one control plot is pictured for each site. Oyster reefs are composed of three $25 \mathrm{~m}$ long modules with a total diameter of $65 \mathrm{~m}$. Site abbreviations: NEPaP: Northeast Point-aux-Pins; SPaP: South Point-aux-Pins; AP: Alabama Port
Roland \& Douglass 2005). The $0.6 \mathrm{~km}$ long shoreline of SPaP faces south and is located $15 \mathrm{~km}$ due north of Dauphin Island. The shoreline orientation of SPaP allows for high wind fetch and, therefore, the greatest exposure to wave-induced erosion of the 3 studied marshes. Indeed, the shoreline at SPaP is characterized by steep escarpments, resulting from wave-induced slumping, along its entire length. Spartina alterniflora and Distichlis spicata dominate from the edge of the escarpments to expansive, monospecific stands of $S$. alterniflora, located approximately $20 \mathrm{~m}$ upland from the shoreline. Upland succulents (sea oxeye Borrichia frutescens; saltwort Batus marinus; and glasswort Limonium spp.) and zones of bare sediment are interspersed among the $S$. alterniflora and D. spicata zones. Bare S. alterniflora rhizome mats exposed by high erosion are common at the shoreline edge.

The shorelines at NEPaP and AP are oriented to the southeast, but wind fetch at NEPaP is limited by the presence of Coffee Island, located approximately $5 \mathrm{~km}$ to the southeast. NEPaP is a $1.2 \mathrm{~km}$ long fringing marsh located along the northeast shore of Pointaux-Pins in Mississippi Sound. A continuous, fringing band of Spartina alterniflora is present along most of the shoreline. Escarpments only occur intermittently along the shoreline, particularly in the northern reaches of the site, where the coast bends to the northeast. The presence of emergent $S$. alterniflora is largely due to the gently sloping shoreline, which is characteristic of low-energy shorelines. Monospecific stands of $S$. patens and patches of Juncus roemerianus lie shoreward of the $S$. alterniflora zone, terminating in a high-elevation dyke vegetated with Iva frutescens and Baccharis halimifolia. The zonation pattern landward of the dykes is similar to that described by Stout (1984).

$\mathrm{AP}$ is a $0.6 \mathrm{~km}$ long fringing marsh located on the southwest shore of Mobile Bay, Alabama. The shoreline is characterized by low escarpments and is dominated by bare rhizome mats and intermittent, monospecific stands of Spartina alterniflora and Distichlis spicata. Succulents and straw-colored sedge Cyperus strigosus occur landward of the S. alterniflora and D. spicata zones and give way to $S$. patens. Patches of bare sand are present 
throughout. These stands extend upland before giving way to dense, monospecific stands of Juncus roemerianus.

Based on the intensity of slumping and extensive shoreline scarping of the marsh edge, which serve as proxies for the intensity of shoreline erosion, SPaP represents the highest energy site of the 3 study marshes. NEPaP, which exhibits a gently sloping shoreline and generally continuous fringing band of emergent Spartina alterniflora, represents the lowest energy marsh. Despite the loss of much of the fringing vegetation along the shoreline, escarpment formation at AP is less severe than that at SPaP and the site is classified as one of intermediate disturbance.

\section{Oyster breakwater construction and sampling design}

Experimental blocks, each consisting of a breakwater reef and a paired control plot, were established at each site with treatment and control plots randomly assigned within blocks (Fig. 1). The time of reef construction and the number of experimental blocks differed among sites: SPaP: May 2007, n = 2 blocks; NEPaP: September 2009, n = 4 blocks; AP: October $2007, \mathrm{n}=1$ block. The reefs were constructed of loose oyster shell and composed of three $25 \mathrm{~m}$ reef 'modules' to produce a structure enveloping $65 \mathrm{~m}$ of shoreline. Reinforcing metal fence was added to the reefs at NEPaP. Reef and control plots were separated by $75 \mathrm{~m}$, and blocks were separated by a minimum of $100 \mathrm{~m}$. Offshore distances for reef placement at each site (Fig. 1) were selected so that the height of the reef crest coincided with mean low water level to facilitate recruitment and growth of oysters.

Three transects, each separated by $25 \mathrm{~m}$, were established within each of the reef and control plots $(\mathrm{n}=$ 6 transects per block; NEPaP, $\mathrm{n}=24$ transects; $\mathrm{SPaP}, \mathrm{n}$ $=12$ transects; $\mathrm{AP}, \mathrm{n}=6$ transects). Each transect ran from a permanent shoreline marker, installed at the shoreline edge at the time of reef construction, to an upland boundary. We define the shoreline edge as the escarpment or the location where emergent vegetation first appeared along the transect. If both features were present within the transect, the seawardmost feature was selected as the shoreline edge. Transects at NEPaP terminated at the first occurrence of Iva frutescens or Baccharis halimifolia along the upland dyke $(15.39 \pm 0.73 \mathrm{~m}$, mean transect length \pm $1 \mathrm{SE}$ ), and transects at AP terminated at the edge of the upland Juncus roemarianus meadow (15.37 \pm $1.32 \mathrm{~m})$. Transects at SPaP were fixed at $20 \mathrm{~m}$ due to the lack of upland topography.

\section{Erosional environment}

To characterize the erosional environment, we assessed shoreline retreat and escarpment height at each site. Shoreline position was marked in July 2009, 2010, and 2011 in all transects at NEPaP, SPaP, and AP, and in July 2009 and 2010 in all transects at NEPaP and SPaP. Escarpment height was measured in July 2010 and 2011 in all transects at NEPaP and SPaP, and in July 2010 in all transects at AP. We did not do any recording at AP in July 2011 to prevent interference by additional reefs constructed at the site in the fall of 2010. Annual shoreline retreat was calculated as the change in shoreline position between consecutive years. Annual shoreline retreat from July 2009 to July 2010 and escarpment height in July 2010 were compared among all 3 sites using a blocked, 2way analysis of variance (ANOVA) design. Site and Treatment (Reef versus Control plots) were the fixed factors, and Block, which was nested within Site, was a random factor. Annual shoreline retreat from July 2009 to July 2010 and from July 2010 to July 2011, and escarpment height in July 2010 and 2011 were compared between NEPaP and SPaP using a blocked, 3-way ANOVA. Year Intervals, Site, and Treatment were the fixed factors and Block (nested within Site) was a random factor. All interactions among fixed factors were included in both ANOVA models.

\section{Community composition}

Community composition was characterized at each site by marking the positions of the boundaries that separated dominant floral zones. Zonal boundaries were marked each year in an effort to determine whether changes in zonation, expressed as changes in percent cover by contiguous floral zones, occurred in response to shoreline retreat. Community composition was assessed annually from 2009 to 2011 in all transects at NEPaP and SPaP, and in 2009 and 2010 in all transects at AP. Data were collected annually in July or August 2009 and 2010 in all transects, which corresponds to the conclusion of the growing season of most marsh floral species in the northern GOM (Stout 1984, Mitsch \& Gosselink 2000). In each site, transects were lined up from the shoreline marker to the upland boundaries defined above. Percent cover was visually estimated at $10 \mathrm{~cm}$ intervals throughout the transect along a perpendicular line extending $10 \mathrm{~cm}$ to each transect side, and boundaries defined wherever a species or an inland barren (i.e. zones of bare sediment within floral zones) accounted for $>50 \%$ of the cover. 
Mixed zones were comprised of a composite of species in which no single species accounted for $50 \%$ or more of the total cover by itself. Mixed zones were common within transects but varied in their composition. They were, therefore, pooled into a single category called 'mixed.' Monospecific stands of upland succulents, including Borrichia frutescens, Batis marinus, and Limonium spp., and patches of Juncus roemarianus, were rare and typically found interspersed within stands of Spartina alterniflora and $S$. patens. Therefore, such monospecific stands of succulents and $J$. roemerianus patches were pooled within a single category called 'other.'

The proportional contribution of each zone category to the total transect length was calculated for each transect once per year. Each of our study sites exhibited net shoreline retreat, necessarily resulting in a loss in the areal extent of marsh flora. Our approach, therefore, required that we adjust the length of all transects each year to correct for shoreline retreat and measure the proportional contribution of zones to the transect at the time of measurement. The resulting proportional contributions of floral zones to their respective transects were compared among Sites, Treatments, and Year Intervals using an Analysis of Similarity (ANOSIM). We hypothesized that floral communities in marshes exhibiting low rates of shoreline retreat would maintain the same propor-

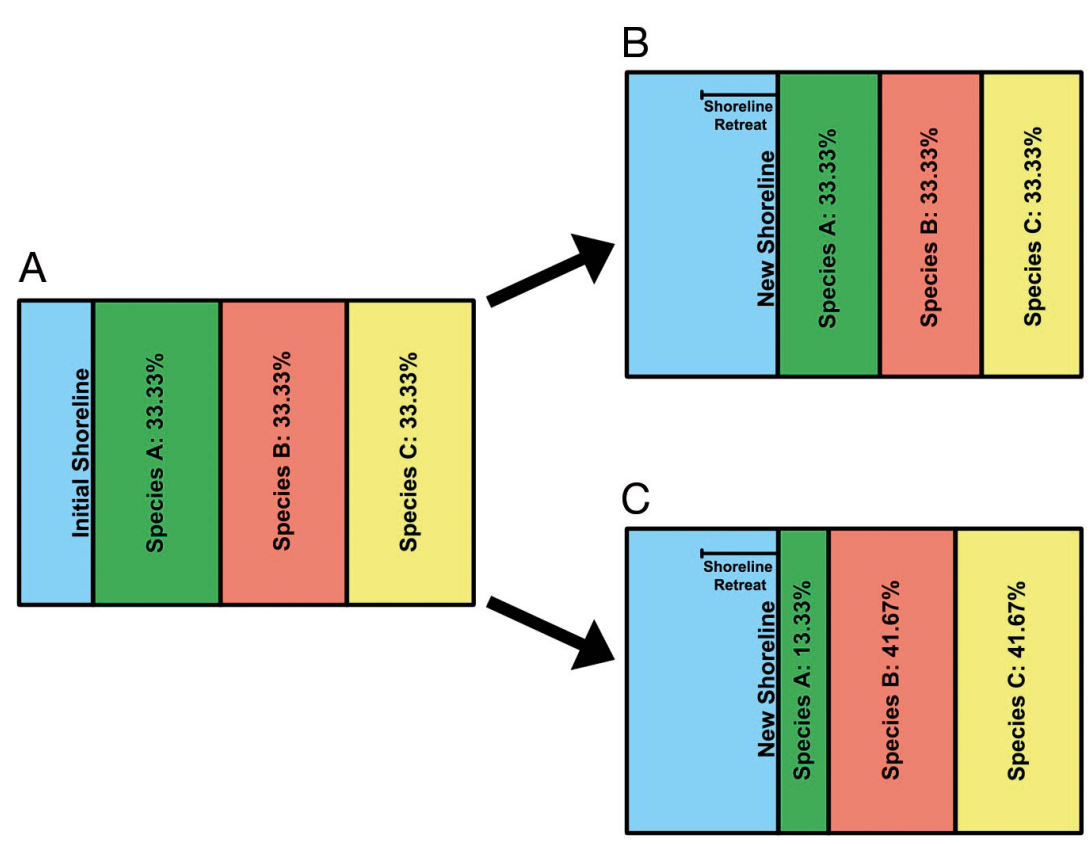

Fig. 2. Hypothesized changes in marsh zonation patterns in response to shoreline retreat: (A) represents the initial marsh state; (B) illustrates the compression of marsh zones with no change in the proportional contribution of each species to floral composition; and (C) illustrates the loss of vegetation at the marsh edge, thereby altering the proportional contribution of species to the zonation sequence tional contribution to each zone relative to the initial zonation pattern (Fig. 2A), albeit in narrower zones (Fig. 2B). Alternatively, we hypothesized that floral communities in marshes exhibiting high rates of shoreline retreat would lose entire floral zones at the shoreline edge (i.e. impose no significant impact on marsh composition; Fig. 2C).

The proportional contribution of the following categories were included in the analysis: (1) bare sediment extending from the shoreline to the first occurrence of vegetation (this category is termed 'shoreline bare'); (2) inland barrens; (3) Spartina alterniflora; (4) S. patens; (5) Distichlis spicata; (6) other (succulents and Juncus roemarianus); and (7) mixed stands. All data were square-root transformed and used to produce a Bray-Curtis similarity matrix between pairs of transects. Separate analyses were conducted for NEPaP, SPaP, and AP in 2009 and 2010, and for NEPaP and SPaP in 2009, 2010, and 2011. For both analyses, site and treatment were first pooled, and community composition was compared among years using a 1-way ANOSIM. Sites and treatment (reef and control) were then compared, pooled among years, using a separate 2-way ANOSIM. The contribution of each zonal category to significant differences among groups was identified using Similarity Percentage (SIMPER) analysis (Clarke \& Warwick 1994). Finally, Multidimensional Scaling (MDS) ordination was used to visualize differences among levels of significant factors.

\section{RESULTS}

\section{Erosional environment}

We did not detect a significant Block effect in our analysis of shoreline loss for all sites during the 2009-2010 interval. The term was, therefore, dropped from the model and shoreline loss analyzed using a 2-way ANOVA with Site and Treatment defined as fixed factors. A significant difference in shoreline loss was detected among sites and between treatments (Table 1A, Fig. 3A). A significant Site $\times$ Treatment interaction was not detected. Shoreline loss was highest at AP and lowest at NEPaP. Shoreline loss at SPaP did not significantly differ from 
Table 1. Comparison of mean shoreline retreat (A) among sites (NEPaP, SPaP and AP) and between treatments (reef and control) during the 2009-2010 interval, and (B) among sites (NEPaP and SPaP) and blocks, and between intervals (2009-2010 and 2010-2011). Factors are defined in 'Materials and methods: Erosional environment'

\begin{tabular}{|lrrrr|}
\hline Source of variation & df & MS & $F$ & p-value \\
\hline (A) & & & & \\
Site & 2 & 0.1794 & 5.33 & 0.009 \\
Treatment & 1 & 0.2272 & 6.74 & 0.014 \\
Site $\times$ Treatment & 2 & 0.0266 & 0.79 & 0.461 \\
Error & 36 & 0.0337 & & \\
(B) & & & & \\
Site & 1 & 29.404 & 5.92 & 0.072 \\
Block(site) & 4 & 4.965 & 2.96 & 0.027 \\
Interval & 1 & 4.421 & 2.64 & 0.110 \\
Treatment & 1 & 0.339 & 0.20 & 0.655 \\
Site $\times$ Interval & 1 & 13.919 & 8.30 & 0.005 \\
Site $\times$ Treatment & 1 & 0.515 & 0.31 & 0.582 \\
Interval $\times$ Treatment & 1 & 10.245 & 6.11 & 0.016 \\
Site $\times$ Interval $\times$ Treatment & 1 & 2.328 & 1.39 & 0.243 \\
Error & 60 & 1.678 & & \\
\hline
\end{tabular}
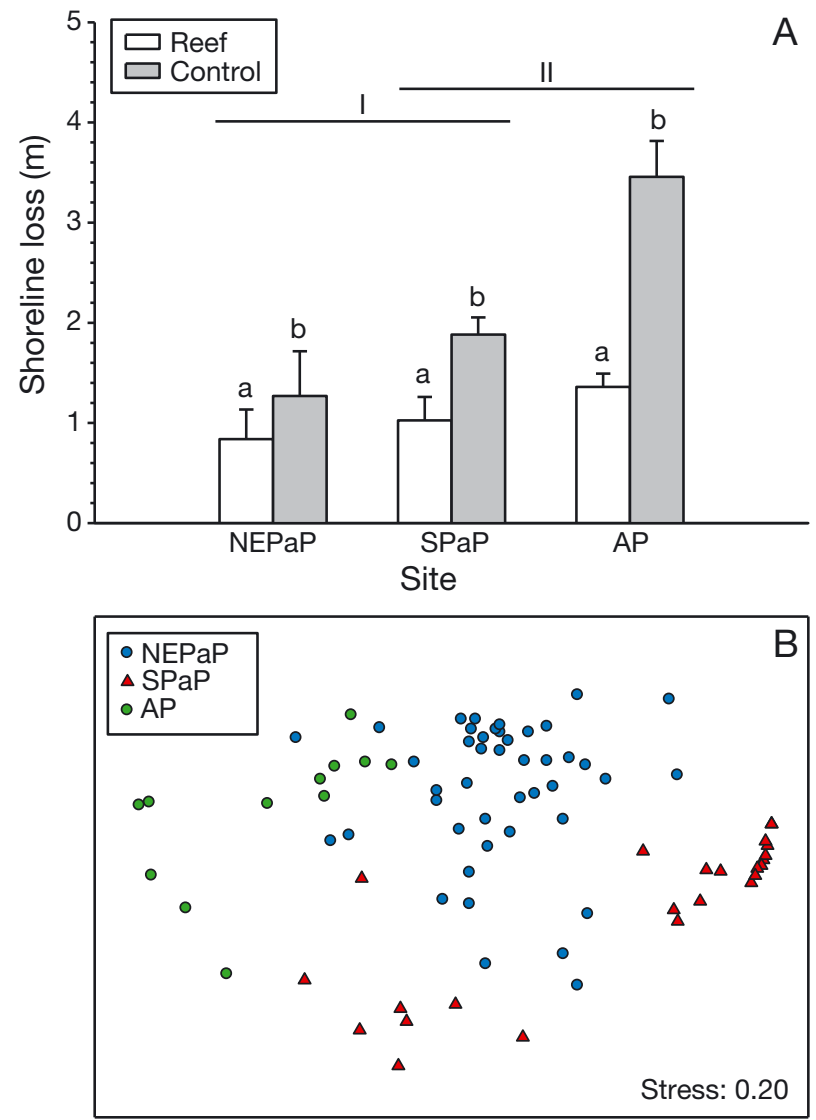

Fig. 3. (A) Comparison of mean shoreline loss among reef and control plots from 2009 to 2010 for all sites, and (B) MDS plot depicting differences in community structure among sites. For (A), sites grouped under the same numbered bar are not significantly different. Treatments with the same letter are not significantly different $(p>0.05)$. Error bars: +1 SE. See Fig. 1 for site abbreviations
$\mathrm{NEPaP}$ or $\mathrm{AP}$, and represents a site of intermediate erosion intensity. Reef plots exhibited significantly lower rates of shoreline loss than controls.

We did not detect a significant effect of Site, Interval, or Treatment in our comparison of shoreline loss between NEPaP and SPaP among the 2009-2010 and 2010-2011 interval (Table 1B, Fig. 4A). A significant Block effect was detected along with a significant Site $\times$ Interval and Interval $\times$ Treatment interaction. Post-hoc comparisons revealed a significant effect of Reefs at SPaP during the 2009-2010 interval, but not for any other Site-Interval combination.

A significant Block effect was not detected in our comparison of mean escarpment height among sites in 2010. The term was dropped from the model and the data were analyzed using a 2-way ANOVA (Table 2A, Fig. 5A). Escarpment height differed significantly among sites but not among treatments. Escarpment height was highest at SPaP, lowest at NEPaP, and AP exhibited intermediate values. A sig-
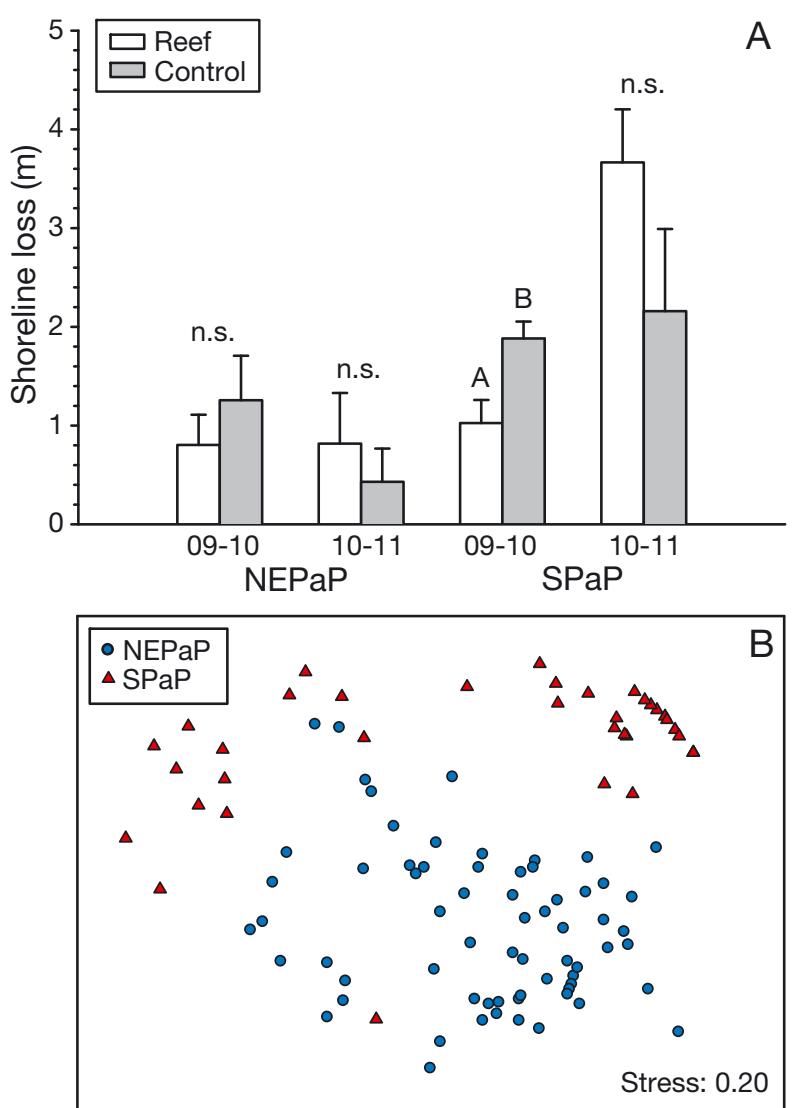

Fig. 4. (A) Comparison of mean shoreline loss among reef and control plots from 2009 to 2011 for NEPaP and SPaP, and (B) MDS plot depicting differences in community structure among sites. No significant differences in shoreline loss were detected between sites, and a significant reef effect was only detected at SPaP for the 2009-2010 interval. Error bars: +1 SE. See Fig. 1 for site abbreviations 
nificant Site $\times$ Treatment interaction was also detected, and post-hoc comparisons revealed a significant effect of Reefs at AP, but not at NEPaP or SPaP. Mean escarpment height differed significantly among sites and blocks, and between years (2010 and 2011) for NEPaP and SPaP (Table 2B, Fig. 5B). SPaP exhibited the highest escarpments, and mean escarpment height was greater in 2010 than in 2011. No significant interaction effects were detected.

\section{Community composition}

Between-year differences in community structure were not distinguishable from within-year differences for both the 2009-2010 interval at NEPaP, SPaP, and AP (Global $\mathrm{R}=0.079 ; \mathrm{p}=0.067$ ) and the 20092011 interval at NEPaP and SPaP (Global $\mathrm{R}=0.037$; $\mathrm{p}=0.016$ ). The 2 -way ANOSIM conducted for the 2009-2010 interval showed a significant separation of sites (Global $\mathrm{R}=0.672$; $\mathrm{p}<0.001$ ), but no separation of reef and control transects (Global $\mathrm{R}=0.079$; $\mathrm{p}<0.018)$. Significant differences were detected among all pairwise comparisons of individual sites (NEPaP vs. SPaP: R $=0.705$; NEPaP vs. AP: $\mathrm{R}=0.556$; SPaP vs. AP: $R=0.700 ; p=0.001$ for all comparisons). Similarly, the 2-way ANOSIM conducted for the 2009-2011 interval yielded a significant separation of communities for NEPaP and SPaP (Global R = 0.617; $\mathrm{p}<0.001$ ), but not between reefs and controls (Global

Table 2. Comparison of mean escarpment height (A) among sites (NEPaP, SPaP and AP) and between treatments (reef and control) in 2010, and (B) between sites (NEPaP and SPaP) and blocks, and among years (2010 and 2011) and treatments (reef and control). Factors are defined in 'Materials and methods: Erosional environment'

\begin{tabular}{|lrccc|}
\hline Source of variation & df & MS & $F$ & p-value \\
\hline A) & & & & \\
Site & 2 & 0.6400 & 61.11 & $<0.001$ \\
Treatment & 1 & 0.0034 & 0.33 & 0.570 \\
Site $\times$ Treatment & 2 & 0.0470 & 4.49 & 0.018 \\
Error & 36 & 0.0105 & & \\
$(B)$ & & & & \\
Site & 1 & 1.795 & 39.18 & 0.003 \\
Block(site) & 4 & 0.046 & 2.62 & 0.044 \\
Year & 1 & 0.150 & 8.55 & 0.005 \\
Treatment & 1 & 0.042 & 2.40 & 0.126 \\
Site $\times$ Interval & 1 & 0.068 & 3.86 & 0.054 \\
Site $\times$ Treatment & 1 & 0.004 & 0.22 & 0.643 \\
Interval $\times$ Treatment & 1 & 0.055 & 3.12 & 0.081 \\
Site $\times$ Treatment & 1 & 0.007 & 0.41 & 0.523 \\
Error & 60 & 0.017 & & \\
& & & & \\
\hline
\end{tabular}

$\mathrm{R}=0.672 ; \mathrm{p}<0.001)$. The MDS results for the 20092010 (Fig. 3B) and 2009-2011 intervals (Fig. 4B) reflect the among-site differences in community composition yielded by the ANOSIM analyses. Threedimensional representations of the data produced substantially lower stress values for the 2009-2010 and 2009-2011 intervals (3-dimensional stress $=0.12$ and 0.13 , respectively). The cohesive nature of the floral communities at each site, as indicated by our ANOSIM and MDS analyses, reflect a lack of temporal differences in the percent cover of contiguous floral zones along transects through time.

Dissimilarities in community composition among sites for the 2009-2010 interval were driven primarily by high abundances of Spartina patens at NEPaP and AP compared to SPaP, high abundances of S. alterniflora at NEPaP and SPaP compared to AP, and a high contribution of barrens, both seaward and inland, at SPaP and AP compared to NEPaP (Table 3).

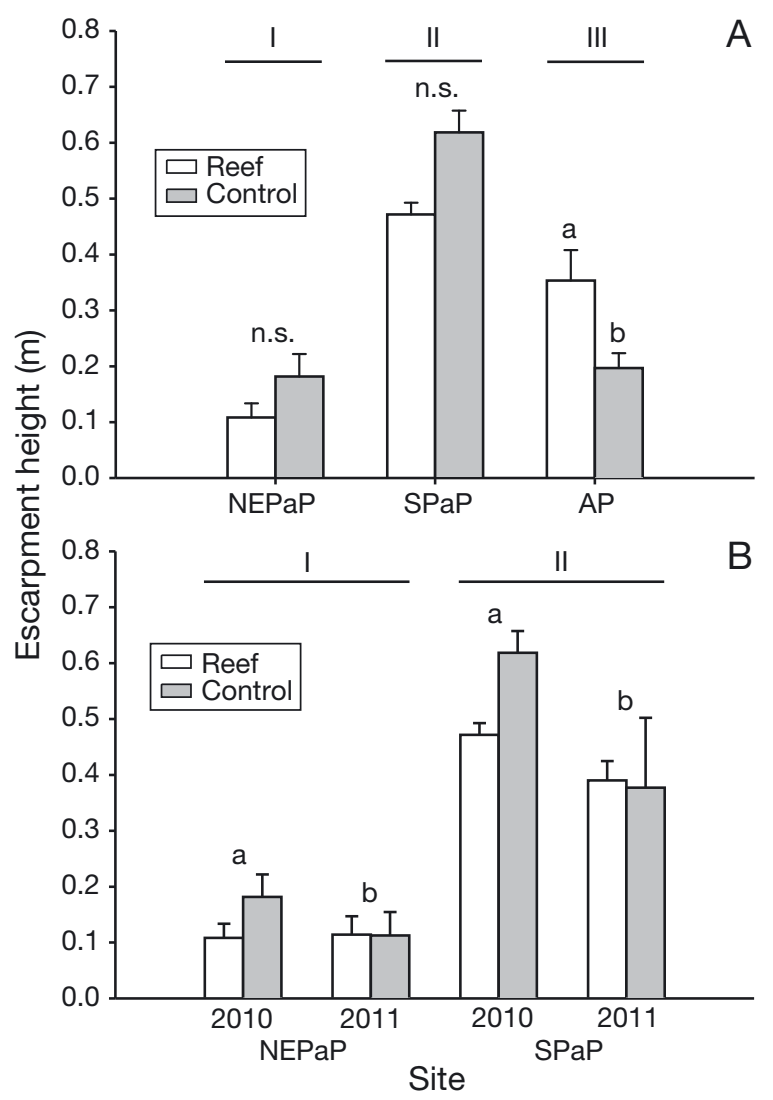

Fig. 5. Mean escarpment height compared among reef and control plots from (A) 2009 to 2010 for all sites, and (B) between time intervals (2009-2010 and 2010-2011) for NEPaP and SPaP. Error bars represent +1 SE. Sites grouped under the same numbered bar are not significantly different. Letters distinguishing significant differences between reef and control plots apply only to their respective sites $(p>$ 0.05). Error bars: +1 SE. See Fig. 1 for site abbreviations 
Dissimilarities in community composition between NEPaP and SPaP for the 2009-2011 interval were driven by primarily by high abundances of $S$. patens at NEPaP compared to SPaP and, to a lesser extent, differences in the abundances of mixed, S. alterniflora, and shoreline bare zones. Among-site differences in community composition and shoreline retreat, averaged for the entire study period, are presented in Fig. 6.

\section{DISCUSSION}

Coastal salt marshes are highly productive habitats that are invaluable to the healthy functioning of estuarine ecosystems, yet they face a gamut of stressors and potential extirpation worldwide (Kennish 2001, Gedan et al. 2009). The northern GOM is no exception (Smith 1990). The 'living shoreline' approach to shoreline protection was successful in creating estuarine habitat at our study sites (Scyphers et al. 2011) and the oyster breakwaters generally slowed shoreline erosion. Contrary to our initial expectations, however, the characteristic floral communities at each of our study marshes remained intact throughout the study period despite severe shoreline loss.

Scyphers et al. (2011) did not detect a significant mitigating effect of the oyster breakwaters on shoreline retreat at $\mathrm{SPaP}$ and $\mathrm{AP}$ during the $2 \mathrm{yr}$ following reef construction. In contrast, we observed a significant reduction in the rates of shoreline retreat at all 3 of our study sites during the 2009-2010 interval. Scyphers et al.'s (2011) assessment of AP included an additional experimental block located to the north of the block assessed in this study, which was dominated by the fringing reed, Phragmites australis. P. australis is not present in the southern block used in this study and the northern block was, therefore, excluded due to the distinct differences in community composition. Dissimilar floral communities including $P$. australis might result in different erosional processes and, therefore, explain the lack of differences in reef
Table 3. SIMPER analysis of transect interval composition among (A) all sites in 2009 and 2010, and (B) NEPaP and SPaP in 2009, 2010, and 2011. Av. prop: average proportion; av. diss.: average dissimilarity; cum. diss. (\%): cumulative percentage of dissimilarity. See Fig. 1 for site abbreviations

\begin{tabular}{|c|c|c|c|c|c|}
\hline $\begin{array}{l}\text { (A) } \\
\text { Category }\end{array}$ & $\begin{array}{c}\text { Av. } \\
\text { prop. } \\
\text { NEPaP }\end{array}$ & $\begin{array}{l}\text { Av. } \\
\text { prop. } \\
\text { SPaP }\end{array}$ & $\begin{array}{l}\text { Av. } \\
\text { prop. } \\
\text { AP }\end{array}$ & $\begin{array}{l}\text { Av. } \\
\text { diss. }\end{array}$ & $\begin{array}{c}\text { Cum. } \\
\text { diss. } \\
(\%)\end{array}$ \\
\hline \multicolumn{6}{|c|}{ Average dissimilarity: $54.92 \%$} \\
\hline Spartina patens & 0.46 & 0.03 & & 13.66 & 24.88 \\
\hline Spartina alterniflora & 0.68 & 0.74 & & 8.67 & 40.67 \\
\hline Shoreline bare & 0.00 & 0.27 & & 7.73 & 54.74 \\
\hline Mixed & 0.16 & 0.18 & & 7.11 & 67.69 \\
\hline Other & 0.21 & 0.05 & & 6.48 & 79.49 \\
\hline Distichlis spicata & 0.18 & 0.11 & & 5.99 & 90.40 \\
\hline \multicolumn{6}{|c|}{ Average dissimilarity: $51.23 \%$} \\
\hline Spartina alterniflora & 0.68 & & 0.22 & 12.75 & 24.88 \\
\hline Inland barrens & 0.09 & & 0.35 & 8.28 & 41.05 \\
\hline Spartina patens & 0.46 & & 0.67 & 6.95 & 54.62 \\
\hline Shoreline bare & 0.00 & & 0.22 & 6.28 & 66.88 \\
\hline Mixed & 0.16 & & 0.17 & 6.18 & 78.94 \\
\hline Distichlis spicata & 0.18 & & 0.14 & 5.42 & 89.52 \\
\hline Other & 0.21 & & 0.10 & 5.37 & 100.00 \\
\hline \multicolumn{6}{|c|}{ Average dissimilarity: $68.95 \%$} \\
\hline Spartina patens & & 0.03 & 0.67 & 19.26 & 27.94 \\
\hline Spartina alterniflora & & 0.74 & 0.22 & 17.24 & 52.95 \\
\hline Shoreline bare & & 0.27 & 0.22 & 8.43 & 65.18 \\
\hline Inland barrens & & 0.16 & 0.35 & 8.23 & 77.12 \\
\hline Mixed & & 0.18 & 0.17 & 7.25 & 87.63 \\
\hline Distichlis spicata & & 0.11 & 0.14 & 5.13 & 95.07 \\
\hline (B) & Av. & Av. & Av. & Cum. & \\
\hline Category & $\begin{array}{l}\text { prop. } \\
\text { NEPaP }\end{array}$ & $\begin{array}{l}\text { prop. } \\
\text { SPaP }\end{array}$ & diss. & $\begin{array}{l}\text { diss. } \\
(\%)\end{array}$ & \\
\hline \multicolumn{6}{|c|}{ Average dissimilarity: $54.80 \%$} \\
\hline Spartina patens & 0.45 & 0.05 & 12.76 & 23.29 & \\
\hline Mixed & 0.21 & 0.23 & 8.59 & 38.96 & \\
\hline Spartina alterniflora & 0.66 & 0.70 & 8.58 & 54.62 & \\
\hline Shoreline bare & 0.00 & 0.25 & 7.15 & 67.67 & \\
\hline Distichlis spicata & 0.17 & 0.13 & 6.07 & 78.74 & \\
\hline Inland barrens & 0.09 & 0.20 & 5.89 & 89.49 & \\
\hline Other & 0.19 & 0.04 & 5.76 & 100.00 & \\
\hline
\end{tabular}

effects observed by Scyphers et al. (2011) at AP. However, we observed significant reef effects at both AP and SPaP during the 2009-2010 interval, likely due to the fact that our study encompassed a longer time period following construction. This suggests a lag in the effectiveness of oyster breakwaters as they become colonized and mature, or that they are subject to the vagaries of inter-annual wind and current regimes. The mitigating effects of the reefs did not persist at NEPaP or SPaP during the 20102011 interval, however. Indeed, the benefits of wave mitigation by the oyster breakwaters was greatest at $\mathrm{AP}$, which was the primary driver of reef effects for the 2009-2010 interval. 

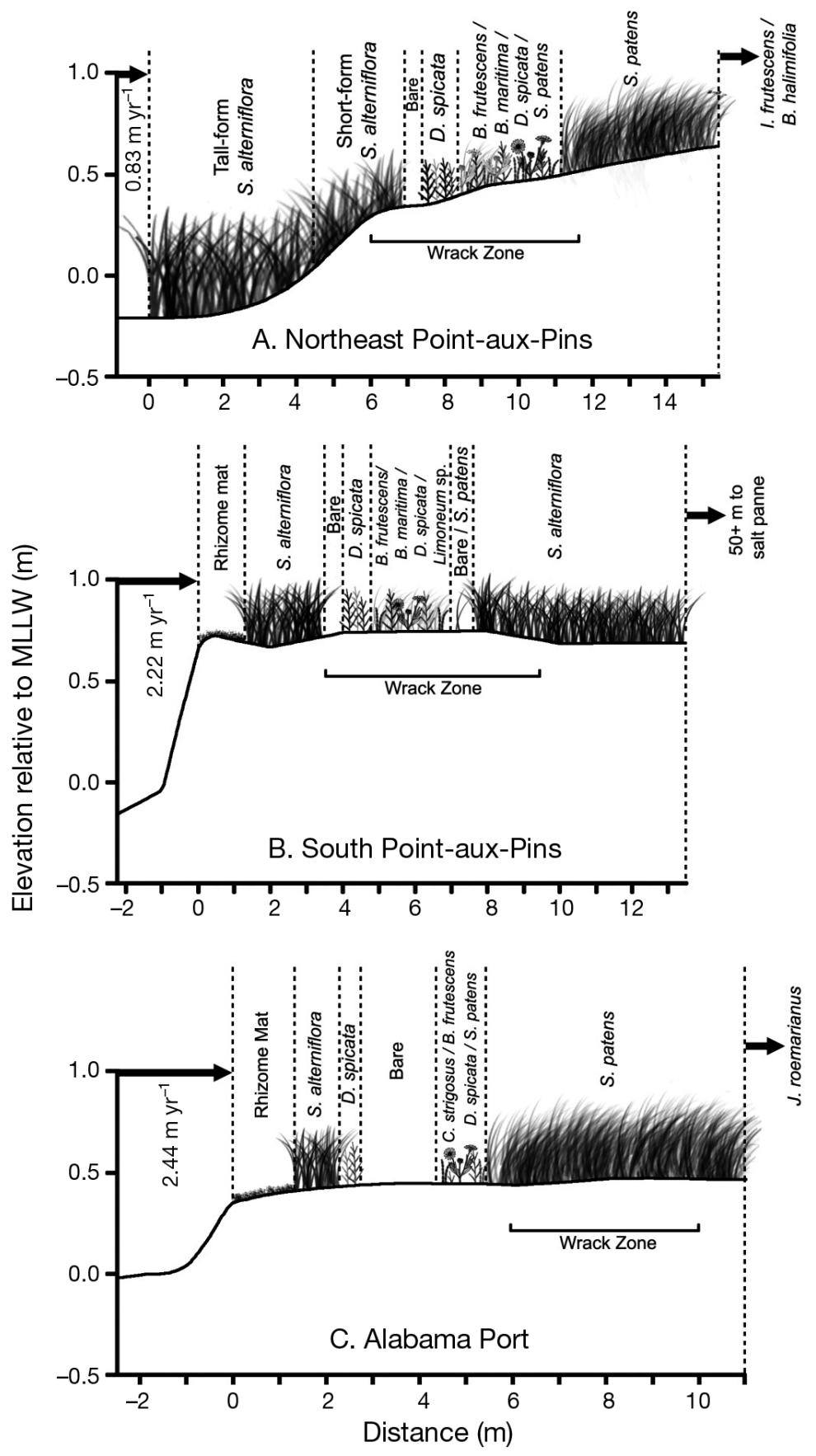

Fig. 6. Generalized shoreline and floral zonation profile for each study site. Transect lengths, floral zone widths, and annual rates of shoreline retreat reflect mean values of all transects pooled for the study period (NEPaP and SPaP: 2009-2011; AP: 2009-2010). MLLW: mean lower low water; see text for species abbreviations

The effects of physical and physiological disturbances on marsh zonation structure is well documented (Pomeroy \& Wiegert 1981, Stout 1984, Bertness \& Ellison 1987, Levine et al. 1998, Emery et al. 2001), but the capacity of salt marshes to respond to stressors at small temporal scales has gone, until now, virtually untested. Rates of shoreline loss observed in this study ranged from 1 to $3 \mathrm{~m} \mathrm{yr}^{-1}$ over a 3-yr period and, given such severe rates of retreat, we hypothesized that this would result in the wholesale loss of entire species bands as the shoreline encroached on upland floral zones. The most immediate and conspicuous effects of shoreline retreat is the reduction in the width of floral zones at the marsh edge. Despite persistently high rates of shoreline loss, the characteristic floral community composition at each of our study marshes remained unchanged throughout the course of our study.

Although high rates of shoreline retreat resulted in a decline in the extent of marsh areal cover, the preservation of marsh communities point to a rapid inland migration of floral zones as cohesive units. Our multivariate analyses in particular show no changes in the percent cover by contiguous floral zones along transects among sites, treatments, or years despite shoreline retreat and, as such, we can infer shoreline loss does not result in changes in zonation composition. Both $\mathrm{SPaP}$ and AP are characterized by high escarpments, extensive Spartina alterniflora rhizome mats and bare substrate at the escarpment's seaward edge, and relatively flat shoreline profiles (Fig. 6). Indeed, waveinduced disturbance was largely limited to the escarpment face and seaward-most edge of the platform (R. Moody pers. obs.). The flat platforms on which the floral zones of SPaP and AP are situated differ largely in the presence of upland $S$. alterniflora zones at SPaP, and $S$. patens zones at the equivalent shoreline position at AP. Nevertheless, the flat platforms provide a means by which seaward floral zones are able to migrate inland as the shoreline retreats. In addition, inland barrens are present at all 3 sites but are the most prevalent, and greatest in extent, at $\mathrm{SPaP}$ where escarpments were highest. This pattern is consistent with the disturbance effects of wrack material deposited on the marsh during storm events. Wrack accumulation is typically ephemeral in the low intertidal due to frequent tidal flushing, but can remain for long periods of time atop high-platform, fringing marshes where they maintain bare sediment on the marsh surface and prevent colonization by marsh plants (Bertness \& Ellison 1987, Tolley \& Christian 1999). 
In contrast, NEPaP exhibits a gently sloping shoreline and a band of emergent, tall-form Spartina alterniflora at its seaward edge, which is indicative of low- to moderate-energy shores (Stout 1984, Levine et al. 1998). Although rates of shoreline loss were low at NEPaP, the observed maintenance of community structure through time suggests that the displacement of $S$. alterniflora at the seaward edge was compensated by changes in floral zones in the upper reaches of the zonation sequence. Furthermore, the lack of shoreline escarpments permit more frequent and ephemeral wrack deposition relative to material deposited upon marsh platforms. This, in part, explains the more prominent occurrence of patchy zones of succulents and mixed zones, and low occurrence of large bare patches (relative to SPaP and AP), within the wrack zone at NPaP (Fig. 6).

In summary, differences in community composition across sites, but not between breakwater treatments and years, suggest that the differences in composition are not due to differences in erosion intensity, but to other contrasts across sites. Our comparisons of marsh structure among all 3 sites $(\mathrm{NEPaP}, \mathrm{SPaP}$, and AP) for the 2009-2010 interval indicated that floral composition varied among sites, but the shoreline loss rate from 2009 to 2010, and the reduction in that loss rate due to breakwaters did not have an effect on marsh structure. The 2009-2010 results were qualitatively similar to the analyses done with NEPaP and SPaP from 2009 to 2011; significant differences in marsh structure were found between the 2 sites, but not among years or between reef treatments, even though these 2 factors had some impact on shoreline loss. Furthermore, our comparison of floral composition between NEPaP and SPaP during the 2009-2010 and 2010-2011 intervals retained distinct floral compositions within sites when no significant differences in erosional environments were present among sites. Our results indicate that marsh structure is retained within sites despite varying yearly erosion rates and the palliating effect of breakwaters. Thus, our findings suggest that shoreline erosion has little, if any, impact on floral composition when expressed as changes in the percent cover of contiguous floral zones. The retention of floral compositions within sites suggests that site-specific shoreline profiles are retained (Fig. 6) as the shoreline retreats and that marshes can adapt by migrating inland while maintaining their distinctive compositions. We cannot, however, rule out the possibility that centuries of chronic shoreline erosion have played a role in the formation of distinct marsh communities in the region and that different compaction patterns might become evident over longer time scales.

The cohesive nature of the floral communities at each study site implies a process by which marshes maintain their zonation structure by effectively migrating inland as the shoreline recedes. It is likely that a threshold rate of erosion exists beyond which shoreline loss will outpace floral acclimation. We observed annual rates of shoreline loss in excess of $4 \mathrm{~m} \mathrm{yr}^{-1}$, which suggests that such a threshold would occur only under the most severe of erosional conditions. Although our results lend a degree of optimism for the retention of marsh structure and floral diversity in response to chronic shoreline loss, the inland migration of marsh zones will, nevertheless, ultimately be limited by upland topology and other factors limiting the area available for marsh colonization.

Living shoreline approaches have been shown to facilitate the successful ecological restoration of nearshore environments, and the presence of oyster breakwaters generally reduce rates of shoreline retreat. Despite significant and substantial among-site differences in rates of shoreline retreat, our studies of marsh communities suggests that salt marshes in the northern GOM can accommodate change brought about by chronic disturbances. Protection and mitigation of the marsh edge is, nevertheless, vital for the long-term preservation of fringing salt-marsh vegetation and upland floral diversity. Further shoreline mitigation techniques will require a coalescence of successful engineering and ecological approaches to attain the successful restoration of habitat and ecosystem functioning.

Acknowledgements. We thank R. Gamble, J. Goff and S. Sharma for their assistance in the field. This project was funded by NOAA Fisheries Emergency Disaster Relief Program (EDRP) Funds, Grant No. NA06NMF4540319, administered through the Alabama Department of Conservation and Natural Resources. This is DISL contribution no. 405.

\section{LITERATURE CITED}

Bertness MD, Ellison AM (1987) Determinants of pattern in a New England salt marsh plant community. Ecol Monogr 57:129-147

Bruno JF, Kennedy CW (2000) Reduction of wave-related disturbance in cobble beach habitats by Spartina alterniflora: importance of patch size. Oecologia 122:98-108

Bruno JF, Stachowicz JJ, Berntess MD (2003) Inclusion of facilitation into ecological theory. Trends Ecol Evol 18: $119-125$

Clarke KR, Warwick RM (1994) Change in marine communities: an approach to statistical analysis and interpretation. Natural Environment Research Council, Plymouth 
Coen LD, Brumbaugh RD, Bushek D, Grizzle R and others (2007) Ecosystem services related to oyster restoration. Mar Ecol Prog Ser 341:303-307

Connell JH (1978) Diversity in tropical rain forests and coral reefs. Science 199:1302-1310

Dame RF, Patten BC (1981) Analysis of energy flows in an intertidal oyster reef. Mar Ecol Prog Ser 5:115-124

- Emery NC, Ewanchuk PJ, Bertness MD (2001) Competition and salt-marsh plant zonation: stress tolerators may be dominant competitors. Ecology 82:2471-2485

Fraterrigo JM, Rusak JA (2008) Disturbance-drive changes in the variability of ecological patterns and processes. Ecol Lett 11:756-770

Gedan KB, Silliman BR, Bertness BD (2009) Centuries of human-driven change in salt marsh ecosystems. Annu Rev Mar Sci 1:117-141

> Gleason ML, Elmer D, Pien NC (1979) Effects of stem density upon sediment retention by salt marsh cord grass, Spartina alterniflora Loisel. Estuaries 2:271-273

Kennish MJ (2001) Coastal salt marsh systems in the U.S.: a review of anthropogenic impacts. J Coast Res 17: 731-748

Kneib RT, Wagner SL (1994) Nekton use of vegetated marsh habitats at different stages of tidal inundation. Mar Ecol Prog Ser 106:227-238

Levine JM, Brewer JS, Bertness MD (1998) Nutrients, competition and plant zonation in a New England salt marsh. J Ecol 86:285-292

Mendelssohn IA, McKee KL, Patrick WH (1981) Oxygen deficiency in Spartina alterniflora roots: metabolic adaptation to anoxia. Science 214:439-441

Meyer DL, Townsend EC, Thayer GW (1997) Stabilization and erosion control value of oyster clutch for intertidal marsh. Restor Ecol 5:93-99

Minello TJ, Able KW, Weinstein MP, Hays CG (2003) Salt marshes as nurseries for nekton: testing hypotheses on density, growth and survival through meta-analysis. Mar Ecol Prog Ser 246:39-59

Mitsch WJ, Gosselink JG (2000) Wetlands. Wiley, New York, NY

> Möller I (2006) Quantifying saltmarsh vegetation and its effect on wave height dissipation: results from a UK east coast saltmarsh. Estuar Coast Shelf Sci 69:337-351

Morgan PA, Burdick DM, Short FT (2009) The functions and values of fringing salt marshes in northern New England, USA. Estuar Coast 32:483-495

Meyer DL, Townsend EC (2000) Faunal utlization of created intertidal eastern oyster (Crassostraea virginica) reefs in the Southeastern United States. Estuaries 23:34-45

Niering WA, Warren RS (1980) Vegetation patterns and processes in New England salt marshes. Bioscience 30: 301-306

NRC (National Research Council) (2007) Mitigating shore erosion along sheltered coasts. National Research Council, National Academies Press, Washington, DC

$>$ Paine RT (1974) Intertidal community structure. Experimental studies on the relationship between a dominant competitor and its principal predator. Oecologia 15:93-120

Paine RT, Tegner MJ, Johnson EA (1998) Compounded

Editorial responsibility: Jana Davis,

Annapolis, Maryland, USA perturbations yield ecological surprises. Ecosystems 1: 535-545

Peterson GW, Turner RF (1994) The value of salt marsh edge vs interior as a habitat for fish and decapod crustaceans in a Louisiana tidal marsh. Estuar Coast 32:483-495

Peterson CH, Grabowski JH, Powers SP (2003) Estimated enhancement of fish production resulting from restoring oyster reef habitat: quantitative valuation. Mar Ecol Prog Ser 264:249-264

> Petraitis PS, Latham RE, Niesenbaum RA (1989) The maintenance of species diversity by disturbance. Q Rev Biol 64: 393-418

Phillips JD (1986) Coastal submergence and marsh fringe erosion. J Coast Res 2:427-436

Pickett STA, White PS (1985) The ecology of natural disturbance and patch dynamics. Academic Press, New York, NY

Pomeroy LR, Wiegert RG (1981) Ecology of a salt marsh. Springer, New York, NY

Prahalad VN, Kirkpatric JB, Mount RE (2011) Tasmanian coastal saltmarsh community transitions associated with climate change and relative sea level rise 1975-2009. Aust J Bot 59:741-748

Roland RM, Douglass SL (2005) Estimating tolerance of Spartina alterniflora in coastal Alabama. J Coast Res 21: 453-463

Schroeder WW, Wiseman WJJ (1985) An analysis of the winds (1974-1984) and sea level elevations (1973-1983) in coastal Alabama. MASGP-84-024: i-102, MississippiAlabama Sea Grant Consortium Publication

Scyphers SB, Powers SP, Heck KL Jr, Byron D (2011) Oyster reefs as natural breakwaters mitigate shoreline loss and facilitate fisheries. PLoS ONE 6:e22396

Silliman BR, van de Koppel J, Bertness MD, Stanton LE, Mendelssohn IA (2005) Drought, snails, and large-scale die-offs of southern U.S. salt marshes. Science 310: 1803-1806

Smith E (1990) Regimes contributory to progressive loss of Alabama coastal shoreline and wetlands. Gulf Coast Assoc Geol Soc Trans 40:793-796

Sousa WP (2001) Natural disturbance and the dynamics of marine benthic communities. In: Bertness MD, Gaines SD, Hay ME (eds) Marine community ecology. Sinauer Associates, Sunderland, MA, p 85-130

Stout JP (1984) The ecology of irregularly flooded salt marshes of the northeastern Gulf of Mexico: a community profile. Biol. Rep. 85, US Fish and Wildlife Service

Syvitski JPM, Vörösmarty CJ, Kettner AJ, Green P (2005) Impact of humans on the flux of terrestrial sediments to the global coastal ocean. Science 308:376-380

Tolley PM, Christian RR (1999) Effects of increased inundation and wrack deposition on a high salt marsh plant community. Estuaries 22:944-954

White PS, Jentsch A (2001) The search for generality in studies of disturbance and ecosystem dynamics. Prog Bot 62: 399-450

> Wolters M, Bakker JP, Bertness MD, Jefferies RL, Möller I (2005) Saltmarsh erosion and restoration in south-east England: squeezing the evidence requires realignment. J Appl Ecol 42:844-851

Submitted: April 30, 2012; Accepted: May 8, 2013

Proofs received from author(s): July 14, 2013 